\title{
Selectivity of Incilius valliceps (Anura: Bufonidae) tadpoles on freshwater zooplankton
}

\section{Selectividad de los renacuajos de Incilius valliceps (Anura: Bufonidae) sobre el zooplancton de agua dulce}

\author{
Brianna Joan Jacobson, Adrián Cervantes-Martínez and Martha Angélica Gutiérrez-Aguirre
}

Universidad de Quintana Roo, Unidad Académica Cozumel. Av. Andrés Quintana Roo con calle 110 Sur, s/n frente a la Col. San Gervasio. Cozumel, Quintana Roo, Mexico e-mail: adcervantes@uqroo.edu.mx

Recibido: 14 de diciembre de 2015. Aceptado: 29 de mayo de 2017.

Jacobson B. J., A. Cervantes-Martínez and M. A. Gutiérrez-Aguirre. 2017. Selectivity of Incilius valliceps (Anura: Bufonidae) tadpoles on freshwater zooplankton. Hidrobiológica 27 (2): 211-217. D0l: 10.24275/uam/izt/dcbs/hidro/2017v27n2/CervantesM

\begin{abstract}
Background. The dietary preferences of tropical tadpoles and the way they interact with zooplankton often go unstudied in aquatic ecosystems. Goals. We investigated the interactions between Incilius valliceps tadpoles and a freshwater zooplankton community found in an artificial aquatic pond located on Cozumel Island in Quintana Roo, Mexico. Methods. We determined zooplankton abundance, richness, the Shannon-Wiener diversity index, and the proportion of each zooplankton species in the environment. We also evaluated characteristics of the tadpole population such as body size, abundance, and proportion of prey ingested as determined by stomach content analysis. We used the Jacobs selectivity index to determine tadpole prey of preference. Results. The rotifers Anuraeopsis fissa and an unidentified species of Bdelloidea group were dominant among the eight zooplankton species consumed. The selectivity index showed that $I$. valliceps tadpoles preferred to consume macro-zooplankton (ostracods and cladocerans) instead of the rotifer species available. Tadpoles positively chose Cypridopsis vidua throughout their growth and development and Moina wierzejskii during their early developmental stages, and negatively selected the rotifer species of the one unidentified species of Bdelloidea, A. fissa, and Epiphanes brachionus. In the presence of tadpoles, Keratella americana, Lepadella patella, and Lecane luna were either present in extremely low abundances or not found in the aquatic community, and $M$. wierzejskil produced males and resistant eggs. Conclusions. The findings of this study clarify the dietary needs of tropical tadpoles and their role in aquatic ecosystems.
\end{abstract}

Key words: Aquatic, feeding, freshwater, preferences, tropical zooplankton.

\section{RESUMEN}

Antecedentes. Las preferencias de alimento de renacuajos tropicales y la manera en que interactúan con el zooplancton, han sido poco estudiadas en los ecosistemas acuáticos. Objetivos. Se estudiaron las interacciones entre renacuajos de Incillius valliceps y una comunidad de zooplancton de agua dulce en un sistema acuático artificial de Cozumel, Quintana Roo, México. Métodos. Se determinó la abundancia y riqueza de zooplancton, la diversidad de Shannon-Wiener y la proporción de cada especie de zooplancton en el ambiente. La preferencia de presas de los renacuajos se determinó con el índice de selectividad de Jacobs. Resultados. Los rotíferos Anuraeopsis fissa y una especie no identificada de bdeloideo, fueron dominantes entre las ocho especies de zooplancton presentes en el ambiente acuático. El índice de selectividad mostró que los renacuajos consumieron con mayor frecuencia al macrozooplancton (ostrácodos y cladóceros) en lugar de las especies de rotíferos disponibles: seleccionaron positivamente a Cypridopsis vidua durante todo su crecimiento y desarrollo y a Moina wierzejskii en las etapas más tempranas de su desarrollo. Se registró selectividad negativa para la especie no identificada de bdeloideo, A. fissa y Epiphanes brachionus. En la presencia de los renacuajos, Keratella americana, Lepadella patella y Lecane luna se ausentaron de la comunidad, o fueron poco abundantes y $M$. wierzejskii produjo machos y huevos de resistencia. Conclusiones. Los resultados de este trabajo aportan información en cuanto la dieta de renacuajos tropicales y su papel en los ecosistemas acuáticos.

Palabras claves: Acuático, alimentación, agua dulce, preferencias, zooplancton tropical. 


\section{INTRODUCTION}

The toad Incilius valliceps (Wiegmann, 1833) is common on Cozumel Island, and their distribution ranges widely throughout the states of Oaxaca, Chiapas, and the Yucatan Peninsula in Mexico (Ochoa-Ochoa et al., 2006). Although this toad is not yet considered threatened or endangered (Rojas-Canales \& Ríos-Valdez, 2012), the decline of amphibian species, in general, is of great concern, especially in Latin America (Young et al., 2000). Information regarding tadpole food preferences is scarce, but they often act as detritivores, herbivores, carnivores, or omnivores (Altig et al., 2007). By examining the gut contents, we can better understand the dietary needs of tadpoles and thus obtain a complete understanding of the ecological role that they play. The ecological behavior of freshwater zooplankton is affected by a wide variety of biotic and abiotic factors. Predation is known to influence the behavior of zooplankton and produces effects that can be noticed in the population size, the production of ephippial (resting) eggs, and the distribution of zooplankton throughout the limnetic zone (Lampert \& Sommer, 2007). The effect of fish, copepod, freshwater shrimp, and insect larva predation on communities of zooplankton has been well documented (0'Brien, 1979; Vijverberg et al., 1990; DeVries \& Stein, 1992; Gliwicz \& Umaña, 1994; Jawahar-Ali et al., 1996; Fernando, 2002; Romare et al., 2003; Cervantes-Martínez, 2005). However, zooplankton interaction with tadpoles remains largely unstudied; only a few studies have investigated this relationship, such as the one performed by Hamilton et al. (2012) that identified the predator-prey relationship that exists between cladocerans (Daphnia pulex Leydig, 1860) and tadpoles (Rana aurora Baird \& Girard, 1852) and recognized the importance of cladocerans in the tadpole diet. Given the lack of information related to the feeding habits of tropical tadpoles and their relationship with zooplankton, we aimed to identify the dietary preferences of $l$. valliceps tadpoles and the way in which their presence influenced zooplankton richness and abundance in a small artificial pond, where these organisms are present throughout the year.

\section{MATERIALS AND METHODS}

Sample collection. We undertook biological collections from one artificial pond located on the campus of the University of Quintana Roo $\left(20^{\circ}\right.$ 29' 18.3" N and 86 56' 22.8" W) on Cozumel Island, Mexico, between June 2011 and January 2012, covering the entire rainy season which favors anuran oviposition (Cedeño-Vázquez et al., 2006). The volume of the pond remained nearly constant $\left(4 \mathrm{~m}^{3}\right)$, had a depth $<1.5 \mathrm{~m}$, and was filled exclusively with rain water.

We collected zooplankton samples monthly using a van Dorn bottle; we filtered $5 \mathrm{~L}$ of water through a zooplankton net with a mesh size of $45 \mu \mathrm{m}$. We took duplicate samples at a depth of $0.5 \mathrm{~m}$ and preserved them according to standard methods for further observation (ElíasGutiérrez et al., 2008).

We took samples of $I$. valliceps tadpoles once a month for three months, using a mosquito-netting-like sieve to collect as many tadpoles as possible within 5 minutes. We introduced the net to the center of the system and, using a weight, made it rest on the bottom. After the specified time had passed, we removed the net in a swift upward motion trapping any tadpoles that had rested on the bottom and those found in the water column. We captured between 15 to 30 individuals in the months in which tadpoles were present (July, September, and
October), with the exception of July (only six individuals). We preserved all tadpoles following standard methods for the posterior gut content analysis (Dutra \& Callisto, 2005).

Laboratory. To evaluate the prey availability in the system, we analyzed the monthly average zooplankton abundance and diversity (S). We estimated the abundance of each zooplankton species using total counts (Lewis, 1979), or the aliquot method for those samples that had extremely large quantities of zooplankton (Oscoz et al., 2006). In order to identify zooplankton species, we used taxonomic keys from Koste (1978), Victor (2002), Kutikova (2002), and Elías-Gutiérrez et al. (2008). We calculated the availability of each zooplankton species as the proportion of each species, relative to the total number of individuals pertaining to the zooplankton community. We quantified the diversity of zooplankton species using the Shannon-Wiener Index (Shannon \& Weaver, 1949). Shannon-Wiener Index: $\left(\mathrm{H}^{\prime}\right)=-\Sigma p i$ Inpi, where $p i$ is the relative abundance of the species $i$.

In order to describe tadpole predation on zooplankton, we recorded morphological magnitudes for each tadpole: body length, tail length, and total length (Altig \& McDiarmid, 1999). The intestinal contents of the tadpoles were analyzed according to Dutra \& Callisto (2005), and the proportional abundance of zooplankton species in the tadpole intestines was estimated by total count.

We calculated the selectivity of zooplankton species by each tadpole as a monthly average using the Jacobs selectivity index (Jacobs, 1974): $D=(r-p) /((r+p)-2 r p))$, where $r$ is the proportion of a specific prey species in the gut contents and $p$ is the proportion of the specific prey species in the environment. This index $(D)$ ranges from -1 (negative selection), 1 (positive selection), and 0 (no selection) (Lampert \& Sommer, 2007).

We performed a simple linear regression in Statgraphics Centurion v. 10.0 to test if tadpole size played a role in the amount of zooplankton consumed. We transformed the data using $\log (x+1)$.

\section{RESULTS}

Eight zooplankton species were identified as available in the medium: six rotifers:Epiphanes brachionus (Ehenberg,1837), Anuraeopsis fissa Gosse,1851, Keratella americana Carlin, 1943, Lepadella patella (Müller,1773), Lecane Iuna (Müller,1776), and an unidentified species of Bdelloidea group, one cladoceran, i.e., Moina wierzejskii (Richard, 1895), and one ostracod, i.e., Cypridopsis vidua (Müller,1776).

In the zooplankton community, the Shannon-Wiener diversity index $\left(H^{\prime}\right)$ ranged from 0.015 to 1.27 (Fig. 1). In August, October, and December, we confirmed the presence of dominant species (the species of unidentified bdeloideo and $A$. fissa respectively) and lower values in $H^{\prime}$. Meanwhile, the months with higher richness (S) and diversity were June $\left(S=5, H^{\prime}=1.27\right)$, September $\left(S=5, H^{\prime}=0.98\right)$, and November $(S=5$, $H^{\prime}=1$ ) (Fig. 1).

The availability of zooplankton species in the artificial aquatic system varied throughout the study period. E. brachionus was greatly available in the month of July $(68.71 \%)$, while $A$. fissa was available in all months, but especially in October (99.81\%), December (91.52\%), and January (83.25\%). K. americana, L. luna, and L. patella were the species with the least availability throughout the period of study (maximum: $0.06 \%, 0.01 \%$, and $34.78 \%$, respectively). C. vidua was also 


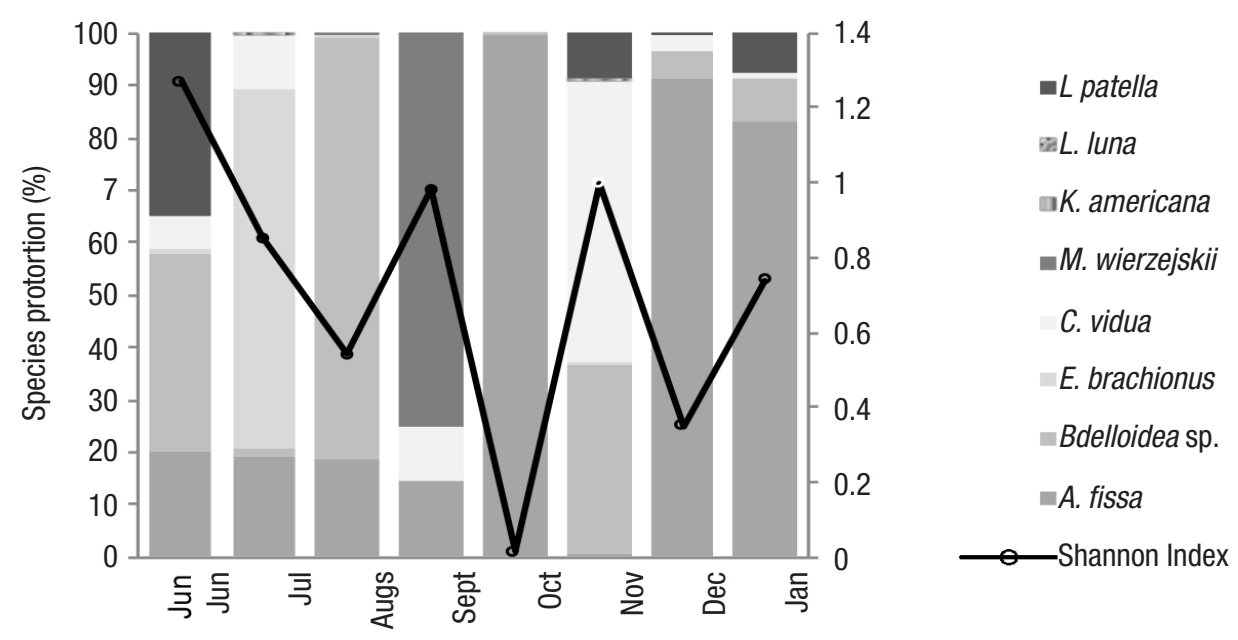

Figure 1. Proportion of every zooplankton species in the environment (for every month (columns) of the study and the corresponding Shannon-Wiener Index values (rows), found in an artificial aquatic pond on Cozumel Island, Mexico.

available throughout the study period in small proportions with the highest availability recorded in November (53.43\%). M. wierzejskii was only available in August (0.55\%) and September (74.95\%) (Fig.1).

Only Bdelloidea sp., C. vidua, M. wierzejskii, A. fissa, and E. brachionus were consumed by I. valliceps, and the species found in higher proportions in the tadpole gut contents were C. vidua (July $83.19 \%$, September 26.54\%, and October 36.28\%) and. M. wierzejskii (September $69.63 \%$ and October 13.5\%) (Fig. 2).

In July, C. vidua was more abundant in the tadpole guts (83.19\%) when the availability was relatively low in the environment $(10.64 \%)$. While in October, $C$. vidua was found frequently in the gut contents of the tadpoles $(36.28 \%)$, but occurred rather rarely in the pond $(0.02 \%)$. The tadpoles examined in September mainly contained $M$. wierzejs- kii (69.63\%), which was also the most abundant zooplankton species in the environment (74.95\%). The species of bdeloidea was not very abundant in the environment when tadpoles were present (July: $1.26 \%$, September: $0.38 \%$, and October: $0.08 \%$ ) and was also only observed in the gut contents in small proportions (July: $0.14 \%$, September: $3.26 \%$, and October: $12.19 \%)$ A. fissa was abundant in all three months (July: $19.26 \%$, September: $14.34 \%$, and October: $99.88 \%$ ), but was absent in all the gut contents with the exception of October (2.75\%) (Figs. 1-2).

The Jacobs selectivity index provided insight into the feeding preferences of $I$. valliceps tadpoles in July, September, and October. $C$. vidua was positively selected; while $M$. wierzejskii changed from not being actively selected (no selection) in September to being positively selected in October; E. brachionus, bdeloidea, and A. fissa were altogether negatively selected (Fig. 3).

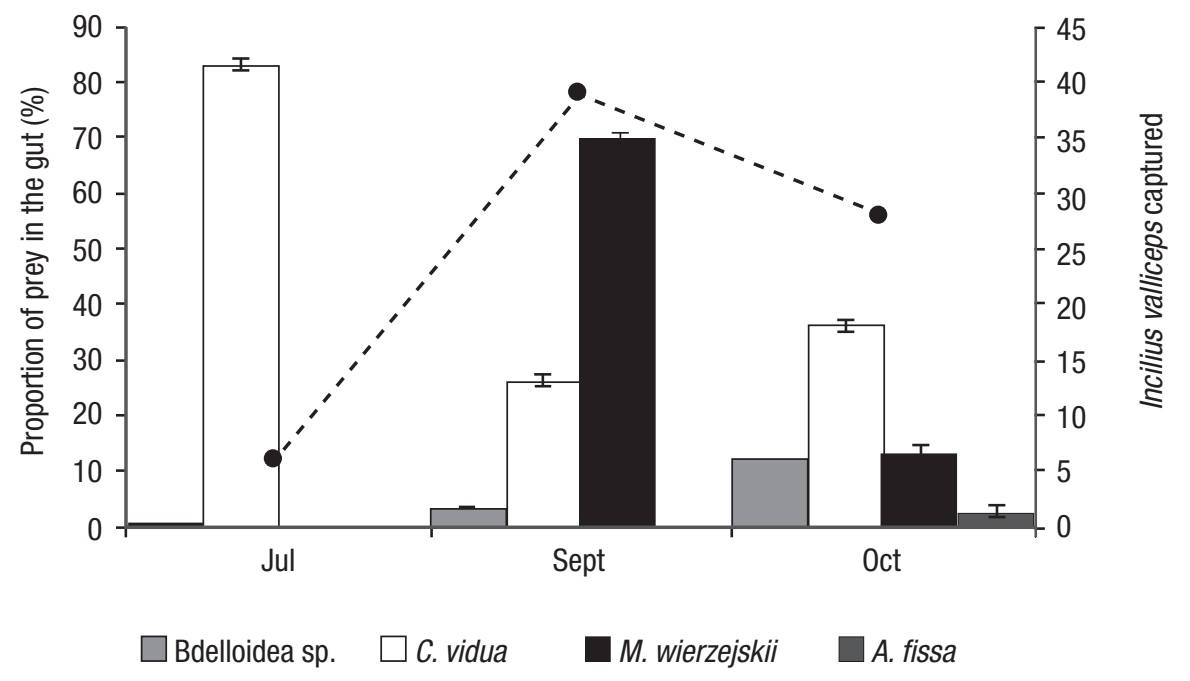

Figure 2. Proportion of each zooplankton prey species present in the tadpole gut contents in each month (columns) and the number of Incilius valliceps tadpoles captured in each month (rows), found in an artificial aquatic pond on Cozumel Island, Mexico. 


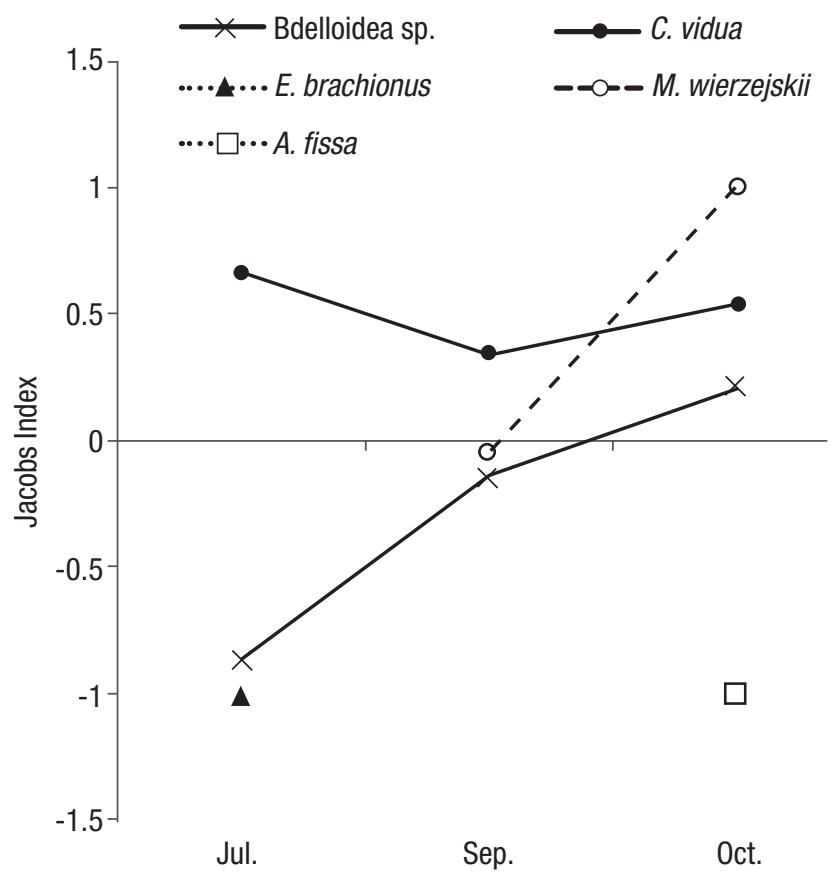

Figure 3. Jacobs selectivity index (monthly average) for every zooplankton species preyed on by the tadpoles each month, found in an artificial aquatic pond on Cozumel Island, Mexico.

The simple linear regression applied revealed the existence of a statistically significant relationship between tadpole size and the number of $C$. vidua $\left(\mathrm{R}^{2}=0.215, p=0.00256\right.$; Fig. 4a), M. wierzejskii $\left(\mathrm{R}^{2}=\right.$ $0.1604, p=0.02021$; Fig. $4 c)$, and bdeloidea consumed $\left(\mathrm{R}^{2}=0.2609, p\right.$ $=0.0175$; Fig. $4 \mathrm{~b}$ ). Larger tadpoles ingested more $C$. vidua and bdeloidea and smaller tadpoles consumed slightly more $M$. wierzejskii.

\section{DISCUSSION}

The abundance and presence of tadpoles in aquatic systems is determined by where adult anurans choose to lay their eggs. Tadpoles are entirely aquatic organisms, meaning that adults must lay their eggs in an aquatic medium where water and resources are abundant, to ensure their development and metamorphosis (Cedeño-Vázquez et al., 2006).

The artificial aquatic system examined in this study contains an established zooplankton community, which explains the relative stability in the number and type of species present. Aquatic systems often reach equilibrium in terms of the number of species present as they age (Dodson et al., 2007; Alfonso et al., 2010). This particular aquatic system is approximately eight years old and, as documented in this study, $A$. fissa, bdelloidea, and $C$. vidua are always present (established species). Species richness each month was always between four to six species. This means that a constant and predictable supply of food is available for the tadpoles inhabiting this pond.

The Jacobs selectivity index applied to the gut contents of the tadpoles showed that the tadpoles of $I$. valliceps clearly preferred $C$. vidua throughout the duration of this study. The positive values of the linear regression between the size of the predator and the amount of $C$. vidua ingested suggest that the tadpoles preferred to consume this ostracod throughout their entire growth and development. The importance of $C$. vidua to the tadpole diet is a reason to perform experimental tests in a controlled environment.

Furthermore, the relationship between tadpole length and the number of $M$. wierzejskii consumed demonstrates that this species was highly consumed by the young tadpoles, but consumption of cladocerans diminished as the tadpoles matured and the availability changed. Sousa Filho et al. (2007) have previously reported slight differences in diet, depending on the size and larval stage of tadpoles.

Although ostracods are known for partially swimming and crawling along the bottom of aquatic systems (Cohen et al., 2007), C. vidua is an efficient swimmer that can enter into the limnetic zone, and is relatively large when compared to rotifer species (Victor, 2002), which may cause this species to be easily seen by the tadpoles. As has been recorded in fish (visual predators), larger prey are positively selected in an effort to conserve energy (Lynch, 1979; Owili \& Omondi, 2003; Gallardo Alanis et al., 2009). This may explain why tadpoles positively selected the larger zooplankton species (C. vidua and $M$. wierzejskil) in this artificial aquatic system.

Even though the tadpoles did not exhibit a clear preference for bdeloidea throughout the study, individuals measuring $4.7 \mathrm{~cm}$ consumed a greater quantity of this rotifer species than their counterparts did. Bdelloidea, $A$. fissa, and E. brachionus were present in the tadpole gut contents, but based on the results of the selectivity index, these species were not preferred. Rotifers are smaller than cladocerans, copepods, or ostracods; as a result, invertebrate predators, rather than vertebrates such as fish or tadpoles (Herzig, 1987), often select them. The fact that these rotifer species were present in the gut contents, available to the tadpoles, but not actively selected by them, suggests that they were incidentally ingested.

$K$. americana, L. patella, and L. luna were the species with the lowest availability or were not detected in the environment when the tadpoles were present. Rotifers have been previously documented as an important source of protein for tadpoles (Rossa-Feres et al., 2004). Yet they also exhibit special behavior such as entering into, or remaining in, a state of diapause (Schröder, 2005), or the ability to stay at lower abundances (Walz, 1997) in the presence of predators as strategies to avoid predation, ensuring that they maintain permanence in the community.

The sharp decline in the population of $M$. wierzejskii observed in the months of September and October (Fig. 1) and the production of males and ephippial eggs can be attributed to tadpole predation of this zooplankton species (supported by the gut content analysis). Predation has been known to affect the life history and behavior of tropical cladocerans (Sarma et al., 2005).

In September, M. wierzejskii was abundant in the aquatic system and in the gut contents of the tadpoles. Meanwhile in October, $M$. wierzejskii was absent in the ecosystem but we continued to find individuals in the gut contents of the tadpoles. In the following months, we did not find any individuals in the gut contents or in the environment. 
We also observed $M$. Wierzejskii with resting eggs in the gut contents of the tadpoles as well as in the environment in the month of September. Males pertaining to this cladoceran species were also present in the environment. Males and resting eggs are often only produced when the zooplankton population finds itself living under environmental stress such as lack of nutrients, competition, and predation (Slusarczyk, 1999; Lampert \& Sommer, 2007).

Considering the small area of the system, and the fact that only one predator dwells within it (personal observation), we hypothesize that the tadpoles produced a profound diminishing effect on the cladoceran population. Tadpoles caused them to reproduce sexually, eventually leading to their disappearance from the artificial aquatic system, which has also been recorded in similar studies (Hamilton et al., 2012; GamaFlores et al., 2013).

Our demonstration in this study regarding tadpole affinity for macrozooplankton, and the way in which these aquatic vertebrates influence zooplankton richness and abundance represents a great advance in understanding and defining the trophic status and dietary needs of tadpoles as well as the ecological role that they play within the aquatic systems they inhabit. This knowledge is essential in the conservation of not only I. valliceps, but also of other anuran species and the ecosystems in which they reside.

\section{ACKNOWLEDGEMENTS}

We would like to thank the University of Quintana Roo, Cozumel for its support. We gratefully acknowledge Jovana Arroyo Castro and Carlos Uh Moo for their field assistance, Rene Calderón-Mandujano for his taxonomic expertise, and Ronald Altig and Nandini Sarma for their knowledgeable contributions during the editing process, all of whom greatly helped to improve earlier versions of this manuscript. ACM would like to thank the CA Vulnerabilidad y Biodiversidad de Sistemas Acuáticos Continentales y Costeros for their financial support.

\section{REFERENCES}

Alfonso, G., G. Belmonte, F. Marrone \& L. Naselli-Flores. 2010. Does lake age affect zooplankton diversity in Mediterranean lakes and reservoirs? A case study from Southern Italy. Hydrobiologia 653 (1): 149164. DOI:10.1007/s10750-010-0350-4

Altig, R., M. R. Whiles \& C. L. TAYLOR. 2007. What do tadpoles really eat? Assessing the trophic status of an understudied and imperiled group of consumers in freshwater habitats. Freshwater Biology 52 (2): 386-395. DOI: 10.1111/j.1365-2427.2006.01694.x

Altig, R. \& R. W. McDiarmid. 1999. Research: Materials and Techniques. In: McDiarmid, R. W. \& R. Altig (Eds.). Tadpoles the Biology of Anuran Larvae. University of Chicago Press, pp. 7-24. D0l: 10.1643/0045-8511(2000)000[1125:BR]2.0.C0;2

Cedeño-Vázquez, J. R., R. R. Calderón-Mandujano \& C. Pozo. 2006. Anfibios de la Región de Calakmul Campeche, México. CONABI0/ ECOSUR/ CONANP/ PNUD-GEF/SHM A.C., Quintana Roo, México. 101 p.

Cervantes-Martínez, A. 2005. Análisis limnológico de dos sistemas cársticos (cenotes) de la Península de Yucatan, México con énfasis en la variación espacial y temporal de zooplancton. Tesis de Doctorado
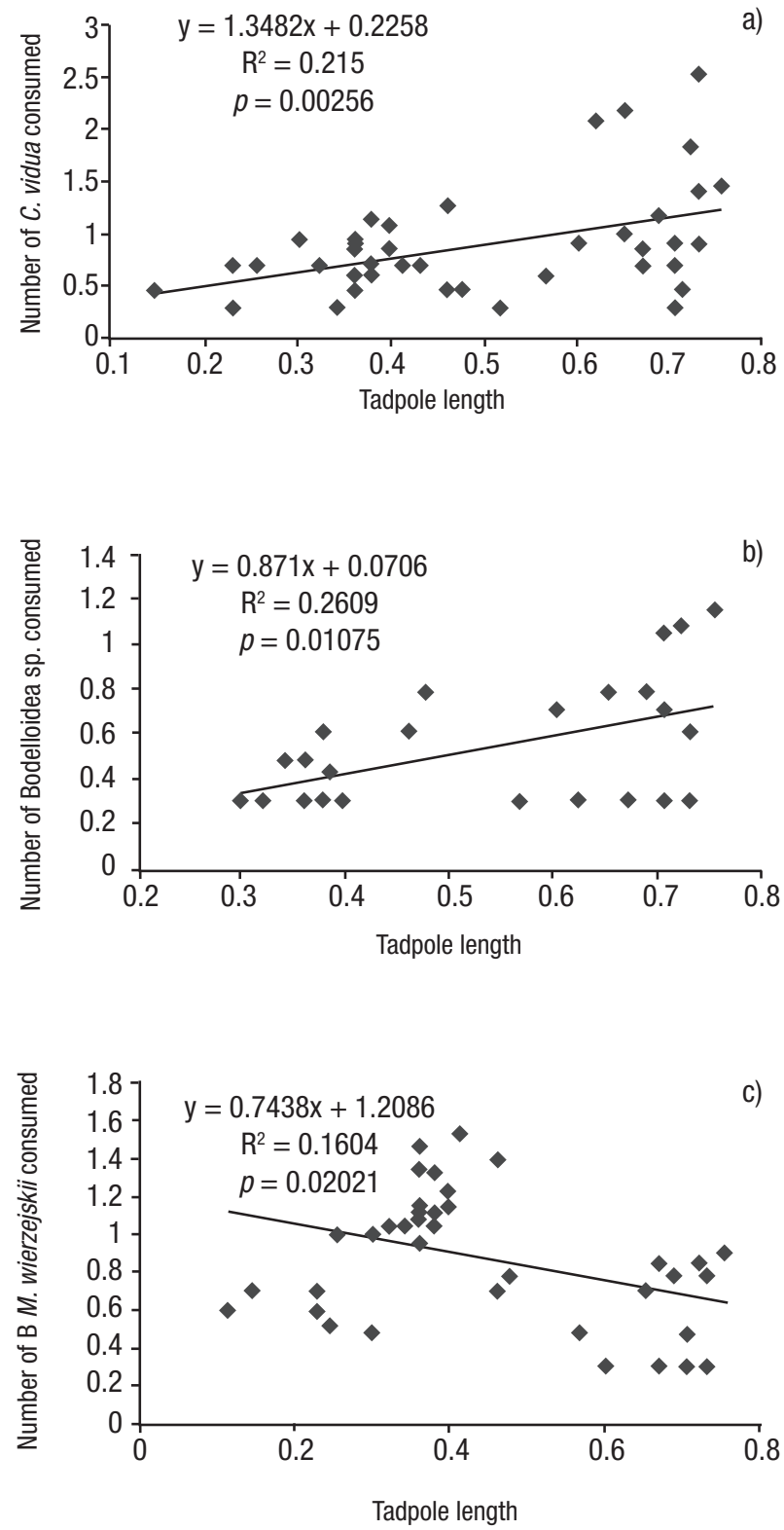

Figures 4 a-c. Simple linear regression between the size of the tadpole and the quantity of zooplankton consumed in an artificial aquatic pond in Cozumel Island, Mexico: a) Cypridopsis vidua, b) Bdelloidea sp., c) Moina wierzejskii.

en Ecología y Desarrollo Sustentable, El Colegio de la Frontera Sur, Chetumal, México. 171p.

Cohen, A., D. Peterson \& R. Maddocks. 2007. Ostracoda. In: Carlton, J. T. (Ed.). The Light \& Smith Manual: Intertidal Invertebrates from Central California to Oregon. University of California Press, California: pp. 417-446.

DeVries, D. \& R. Stein. 1992. Complex Interactions between Fish and Zooplankton: Quantifying the Role of an Open-Water Planktivore. 
Canadian Journal of Fisheries and Aquatic Sciences 49 (6): 12161227. DOl: $10.1139 / f 92-137$

Dodson, S. I., W. R. Everhart, A. K. JandL \& S. J. Krauskopf. 2007. Effect of watershed land use and lake age on zooplankton species richness. Hydrobiologia 579 (1): 393-399. DOI: 10.1007/s10750-006-0392-9

Dutra, S. L. \& M. Calusto. 2005. Macroinvertebrates as tadpole food: Importance and body size relationships. Revista Brasileira de Zoologia 22 (4): 923-927. DOl: 10.1590/S0101-81752005000400018

Elías-Gutiérrez, M., E. Suárez-Morales, M. A. Gutiérrez-Aguirre, M. SilvaBriano, J. Granados-Ramírez \& T. Garfias-Espejo. 2008. Cladocera $y$ copepoda de las aguas continentales. UNAM, ECOSUR, SEMARNAT and CONABIO,Tlalnepantla, Mexico. 322 p.

Fernando, C. H. 2002. Zooplankton and tropical freshwater fisheries. In: Fernando, C.H. (Ed.). A Guide to Tropical Freshwater Zooplankton: Identification, Ecology and Impact on Fisheries. Bakhuys Publishers, pp. 255-275. DOl: 10.2989/16085914.2003.9626605

Gallardo Alanis, J., S. S. S. Sarma \& S. NandinI. 2009. Prey selectivity and functional response by larval red-eyed tetra Moenkhausia sanctaefilomenae (Steindachner, 1907) (Characiformes: Characidae). Brazilian Archives of Biology and Technology 52 (5): 1209-1216. DOI: 10.1590/S1516-89132009000500019

Gama-Flores, J. L., M. E. Huidobro-Salas, S. S. S. Sarma \& S. Nandini. 2013. Effects of allelochemicals released by vertebrates (fish, salamander and tadpole) on Moina macrocopa (Cladocera). Allelopathy Journal 31 (2): 415-425.

GLiwicz, M. Z.\& G. UmanA. 1994. Cladoceran size and vulnerability to copepod predation. Limnology and Oceanography 39 (2): 419-424. DOI: $10.4319 /$ lo.1994.39.2.0419

Hamilton, P., J. Richardson \& B. Anholt. 2012. Daphnia in tadpole mesocosms: trophic links and interaction with Batrachochytrium dendrobatidis. Freshwater Biology 57 (4): 1-8. D0I: 10.1111/j.13652427.2011.02731.x

HeRzIG, A. 1987. The analysis of planktonic rotifer populations: A plea for long-term investigations. Hydrobiologia 147 (1): 163-180. DOI: 10.1007/BF00025739

JACOBS, J. 1974. Quantitative Measurement of Food Selection: A Modification of the Forage Ratio and Ivlev's Electivity Index. Oecologia 14 (4): 413-417. DOI: 10.1007/BF00384581

Jawahar-Ali, J., S. S. S. Sarma \& H. J. Dumont. 1996. Effect of zooplankton type and abundance on prey consumption by the fairy shrimp, Streptocephalus proboscideus (Anostraca: Crustacea). Hydrobiologia 319 (3): 191-202. DOI: 10.1007/BF00013732

Koste, W. 1978. Rotatoria. Die Rädertiere Mitteleuropas. Ein Bestimmungswerk, begründet von Max, vol. 1, 2. Voigt Überordnung Monogononta (Germany). DOI: 10.4319/lo.1981.26.2.0400a

Kutikova, L. A. 2002. Rotifera. In: Fernando, C. H. (Ed.). A Guide to Tropical Freshwater Zooplankton: Identification, Ecology and Impact on Fisheries. Bakhuys Publishers, Leiden, The Netherlands: pp. 23-45. DOI: 10.2989/16085914. 2003.9626605
LAMPERT, W. \& U. SOMmer. 2007. Limnoecology: The Ecology of Lakes and Streams. Oxford Press, New York, New York. 336 p. D0I: 10.1093/ plankt/fbn013

LewIs, W. M. 1979. Zooplankton Community Analysis: Studies on a Tropical System. Springer-Verlag, New York, New York. 164 p. D0l: 10.4319//0.1980.25.5.0966

LYNCH, M. 1979. Predation, competition and zooplankton community structure: An experimental study. Limnology and Oceanography 24 (2): 253-272. DOI: 10.4319/lo.1979.24.2.0253

O'BRIEN, J. W. 1979. The predator-prey interaction of planktivorous fish and zooplankton. American Scientist 67 (5): 572-581.

Ochoa-0choa, L., 0. Flores-Villela, U. García-Vázouez, M. Correa-Cano \& L. Canseco-Márquez. 2006. Bufo valliceps (Sapo del golfo). Área de distribución potencial. Catálogo de metadatos geográficos. Available online at: http://www.conabio.gob.mx/informacion/metadata (downloaded November 6, 2012)

Oscoz, J., F. Campos \& M. Escala-Carmen. 2006. Utilidad de un método de alícuotas para el análisis de la comunidad de macroinvertebrados bentónicos acuáticos. Boletín Real Sociedad Española de Historia Natural (Sección Biología) 101 (1-4): 19-28.

OWIL, A. M. \& R. OMondi. 2003. Predator-prey relationship between zo0plankton and Rastrineobola argentea and juvenile Lates niloticus in the lake-river interface habitats in the Nyanza Gulf of Lake Victoria, Kenya. In: Knaap M. van der\& M. Munawar (Eds.). Lake Victoria Fisheries: Status, Biodiversity and Management. Aquatic Ecosystems Health and Management Society. Ontario, Canada, pp. 1-16.

Rojas-Canales, M. \& A. Ríos-Valdez. 2012. Informe de evaluación ambiental: Sistemas productivos sostenibles y biodiversidad. Comisión Nacional para el Conocimiento y Uso de la Biodiversidad (CONABIO). Available online at: http://www.conabio.gob.mx/web/pdf/SPSB_InformeEvaluacionAmbiental.pdf (downloaded November 6, 2012).

Romare, P. S. Berg, T. Lauridsen \& E. Jeppesen. 2003. Spatial and temporal distribution of fish and zooplankton in a shallow lake. Freshwater Biology 48 (8): 1353-1362. DOI: 10.1046/j.13652427.2003.01081.x

Rossa-Feres, D. C., J. Jim \& M. Goncalves Fonseca. 2004. Diets of tadpoles from a temporary pond in southeastern Brazil (Amphibia, Anura). Revista Brasileira de Zoologia 21 (4): 745-754. D0I: 10.1590/ S0101-81752004000400003

Sarma, S. S. S., S. NandinI \& R. D. Gulati. 2005. Life history strategies of cladocerans: comparisons of tropical and temperate taxa. Hydrobiologia 542 (1): 315-333. DOl: 10.1007/s10750-004-3247-2

SCHRÖDER, T. 2005. Diapause in monogonont rotifers. Hydrobiologia 546 (1): 290-306. DOI: 10.1007/s10750-005-4235-X

Shannon, C.E. \& W. Weaver. 1949. The Mathematical Theory of Communication. University of Illinois Press. Urbana Chicago, Illinois. 144 p.

SlusarczYK, M. 1999. Predator-induced diapause in Daphnia magna may require two chemical cues. Oecologia 119 (2): 159-165. DOI: $10.1007 / \mathrm{s} 004420050772$ 
Sousa Filho, I. F. de, C. C.Branco, A. M. P. Telles de Carvalho-e-Silva, G. R. dA Silva \& L. T. SABAGH. 2007. The diet of Scinax angrensis (Lutz) tadpoles in an area of the Atlantic Forest (Mangaratiba, Rio de Janeiro) (Amphibia, Anura, Hylidae). Revista Brasileira de Zoologia 24 (4): 965-970.

VIctor, R. (2002). Ostracoda. In: Fernando, C.H. (Ed.). A Guide to Tropical Freshwater Zooplankton: Identification, Ecology and Impact on Fisheries. Backhuys Publishers, The Netherlands: pp. 189-233. D0I: 10.2989/ 16085914.2003.9626605

Visverberg, J., M. Boersima, W. van Densen, W. Hoogenboezem, E. Lammens \& W. Moos. 1990. Seasonal variation in the interactions between pisci- vorous fish, planktivorous fish, and zooplankton in a shallow eutrophic lake. Hydrobiologia 207 (1): 279-286.

WALZ, N. 1997. Rotifer life histories and evolution in freshwater plankton communities. In: Streit, B., T. Städler \& C. M. Lively (Eds.). EvoIution Ecology of Freshwater Animals: Concepts and Case Studies. Birkhäuser Verlag Basel, Switezerland: pp. 119-148. DOI: 10.1007/978-3-0348-8880-6_5

Young, B., K. Lips, J. Reaser, R. liáñez, R. Salas, J. Cedeño, L. Coloma, S. Ron, E. La Marca, J. Meyer, A. Muñoz, F. Bolaños, R. Chaves \& D.Romo. 2001. Population Declines and Priorities for Amphibian Conservation in Latin America. Conservation Biology 15 (5): 1213-1223. 